\title{
Унутрашња мотивација за рад библиотекара
}

\author{
Јелена Јовин \\ Библиотека Матице српске, Нови Сад \\ jovinj@bms.ns.ac.rs
}

\begin{abstract}
Сажетак
Библиотекари се међусобно разликују по начину и продуктивности рада: неки од каталогизатора брже постижу норму у броју записа, неке информаторе корисници више „воле“, трећи брже стижу до звања, четврти остварују бројне међународне контакте на конференцијама и друштвеним мрежама, а неки прихватају и прековремени рад. Шта је то што их издваја, прави разлику, што их покреће, даје им снагу, истрајност, жељу и вољу? Поред склопа јединствених црта личности, темперамента, интелигенције, као важна детерминанта у раду издваја се феномен мотивације, коју су проучавали заговорници различитих теоријских праваца из области менаџмента, организационог понашања и психологије рада. Текст обухвата неколико аспеката, почевши од личног, преко аспекта „други“ (колеге, ментори, радна атмосфера), до ширег друштвеног, културног и економског окружења у којем библиотека доприноси и функционише. Чланак има за циљ да укаже на сложену природу и значај унутрашње мотивације за рад кроз сажет приказ најважнијих ставова различитих теоретичара и истраживача, Данијела Пинка, Исака Адижеса, Абрахама Маслова и трансакционих аналитичара, који могу бити смернице за примену у раду библиотекара. Теоријске поставке допуњују примери из библиотечке праксе и искуство аутора у раду са групама библиотекара током радионице посвећене теми мотивације.
\end{abstract}

Кључне речи: библиотекари, мисија, радни стилови, мотивација, циљеви, стручно усавршавање

\section{Мотивација кроз речнике и дефиниције}

„Што се хоће, то се може.“ српска народна пословица

Неопходан састојак за постизање успеха, доступан онима који имају јасно постављен циљ и сврху свога рада, као и истрајност да га остваре, мотивација је у Речнику йсихолоїије Жарка Требјешанина дефинисана речима: „сложен психички процес покретања, усмеравања и регулисања делатности усмерене ка одређеном циљу“. ${ }^{2}$ Она има и моћ утицаја на друге, као што библиотекар може пренети кориснику страст ка читању или ментор своју истраживачку страст ученику. Овај аспект наглашен је у Речнику срӣскоїа језика: „да(ва)ти унутрашњи, вољни подстрек, подстицај, стимуланс (некоме), подстаћи, подстицати, стимулисати (некога на нешто): на рад". ${ }^{3}$ Мотивација делује нестално, можда и неухватљиво, јер је својствена свакој индивидуи на јединствен начин и не постоји универзална чаробна формула за њено настајање.

\footnotetext{
Edukacija, "Srpske narodne poslovice i izreke“, preuzeto 30. 7. 2018, http://edukacija.rs/izreke-i-citati/narodne-poslovice/srpske.

Žarko Trebješanin, Rečnik psihologije (Beograd: Stubovi kulture, 2004), 283.

3 Милица Вујанић и др., Речник срйскоїа језика (Нови Сад: Матица српска, 2007), 733.
} 


\section{Мотивација и инспирација - обе су неопходне за успех}

„Мотивација (и инспирација) је уметност подстицања других да имају жељу да раде оно што ви желите." Двајт Д. Ајзенхауер ${ }^{4}$

У раду са библиотекарима током радионице на тему мотивације, ${ }^{5}$ показала се потреба за разликовањем појмова мотивација и инспирација. По чему се они заправо разликују?

Мошиивација се односи првенствено на снагу воље да се превазиђу препреке на путу ка циљу, али је променљива и често зависи од личне интерпретације и емоционалног доживљаја тренутне ситуације у току процеса постизања циља. У том смислу, отпорнија и учинковитија је инсйирација, као концепт који означава тврдокорнију, аутентичну унутрашњу снагу која раду даје дубљи смисао. Инспирација је више одлика креативног изражавања, као што је био инспирисан аутор графита да на зиду поред Библиотеке шабачке испише поруку „Узми, читај!“, док је мотивација неопходна за рутинске послове, као што је библиотекар, да би постигао повећану месечну норму у инвентарисању новоприспелих књига, подстакнут да ради повећаним интензитетом.

\section{Зашто је мотивација важна?}

„Свакога дана, у сваком погледу, све више напредујем.“"

Ради бољег разумевања овог феномена и његове примене у побољшању радних перформанси, у тексту ће бити описани поједини аспекти мотивације кроз приказ неколико различитих теоријских концепата. У области менаџмента мотивација се истражује са циљем проналажења адекватних организационих формула, ефикасног начина поделе радних задужења, као и принципа делегирања и контроле активности да би се код запослених појавила и одржала воља за квалитетним испуњавањем радних обавеза и тиме обезбедио опстанак и развој предузећа. Тренутно је актуелан флексибилан и динамичан приступ према свакој специфичној ситуацији насупрот општих и нормативних упутстава. ${ }^{7}$ У раду је предност дата личном аспекту унутрашње мотивације, а мање мотивисању других.

\section{Моћ унутрашње мотивације}

„Немојте запошљавати људе које морате да мотивишете, људе чије ставове морате да мењате. Професија менаџмент није за социјалне раднике. Људи које запошљавате би требало да буду мотивисана група од самог почетка. Ваш посао је да их не демотивишете."

Исак Адижес ${ }^{8}$

Прво, посматрајући из шире перспективе, запитајмо се какву улогу играју библиотеке и библиотекари у друштву. Као установе културе из непрофитног државног сектора, њихова сврха

\footnotetext{
${ }^{4}$ Priceless professional development, "How to Define Motivation and Inspiration: the Power of the Difference", preuzeto 25. 7. 2018, https://www.pricelessprofessional.com/define-motivation-and-inspiration.html.

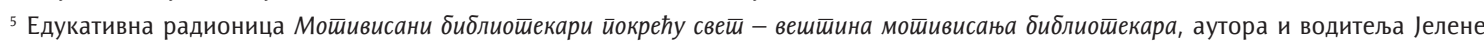
Іовин, акредитована је у Народној библиотеци Србије у оквиру Програма сталног стручног усавршавања запослених у библиотечко-информационој делатности 2017-2018. год. Одржано је 14 радионица са просечном оценом 4,65, а учествовало је 240 библиотекара и књижничара из различитих библиотека у Србији.

6 Популарна сентенца из филма Сјећаш ли се Доли Бел?, потиче од Емила Kуеа, (Émile Coué, 1857-1926), француског психолога и фармацеута, заговорника лечења путем аутосугестије.

${ }^{7}$ Tatjana Milivojević, Motivacija za rad: teorije i strategije (Beograd: „Filip Višnjić", 2009), 31.

${ }^{8}$ Isak Adižes, Misli: povodom 75 godina života i 50 godina rada (Novi Sad: Asee, 2012), 148
} 
је дефинисана Законом о библиотечко-информационој делатности: „Библиотеке, под једнаким условима и без обзира на разлике, обезбеђују свим грађанима остваривање људских права у домену слободе изражавања, стваралаштва, интелектуалних и других грађанских слобода, као и остваривање комуникације с другим грађанима и интелектуалним добрима у земљи и иностранству. “9 Дакле, круцијални циљеви библиотека нису усмерени на стварање профита, већ привлачење (мотивисање) публике квалитетним услугама и сервисима. То би конкретно значило: интересантним програмима у виду филмова, радионица, предавања зарад промовисања књижевности и науке, добрим условима рада, пријатним ентеријером, брзом услугом, љубазним и стручним библиотекарима, уређеним, прецизним и ефикасним електронским каталогом. Да би се обезбедили сви набројани услови у библиотекама, поред материјалних, организационих и кадровских ресурса, постојање мотивисаних библиотекара је conditio sine qua non.

Друго, посматрајући актуелни стандард у држави, основне надокнаде за рад су често испод границе просека, а допунско мотивисање новчаним наградама је најчешће недостижан луксуз. Тада је једино покретачко што преостаје, подстицајна моћ унутрашње мотивације односно, рад подстакнут вредностима као што су: постизање аутономије, тежња ка сталним усавршавањем и тражење смислености и сврсисходности рада. О њима истражује на нов, другачији, можда и утопијски начин, Данијел Пинк ${ }^{10}$ и подстиче на редефинисање постојећих ставова о мотивацији, наводећи различите експерименте који потврђују надмоћ унутрашње над спољашњом (новчаном) мотивацијом. Он наводи пример процеса настанка бесплатне Википедије (и за ауторе и за кориснике), током којег аутори без материјалне надокнаде пишу одреднице ради забаве, жеље да се обавести јавност или подели знање. Слично је и са стварањем Линукса, бесплатног оперативног система који се користи широм света, а који је створила многобројна група програмера волонтерски. Такво понашање, под условом да није праћено незадовољством основном новчаном надокнадом, које није условљено спољашњим наградама и казнама, већ покреће на акцију зарад унутрашњег задовољства, личне испуњености или

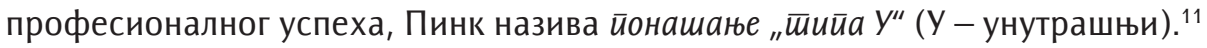

Иако су Пинкови примери настали у сасвим другачијем окружењу, ипак могу бити идеја за личну примену. Размотримо како.

\section{Самосталност у избору начина рада}

„Треба да схватимо да слободом и независношћу које пружамо детету ми дајемо слободу раднику већ спремном за акцију и који, без сопственог рада и активности, не би могао да живи." Марија Монтесори ${ }^{12}$

Унутрашња мотивација се поспешује у условима када је важно направити резултат, при чему поред одговорности, постоји и оно најважније: аушиономија над задатком, временом, тимским радом и техником рада. То би значило, на примеру израде записа у електронској бази, да библиотекар има могућност да самостално одреди којом техником (прво именска, па предметна и децимална обрада, у једном запису или више записа) и којим темпом ће радити (колико записа израђује дневно, да ли ће радити дуже или ће сутра надокнадити данашњи заостатак јер има „клизно радно време“"). Дакле, важно је испунити норму на крају месеца уз слободу

\footnotetext{
„Zakon o bibliotečko-informacionoj delatnosti“, Sužbeni glasnik RS br. 52 (2011), preuzeto 30. 7. 2018, https://www.nb.rs/view_file. php?file_id=3047.

${ }^{10}$ Daniel Pink, Šta nas pokreće: neočekivana istina o ljudskoj motivaciji (Beograd: Laguna, 2011).

${ }^{11}$ Супротно овоме је понашање „йийа C" (C - спољашњи) које је у већој мери подстицано спољашњим наградама, а мање унутрашњим задовољством.

${ }^{12}$ Marija Montesori, Upijajući um (Beograd: Miba Books, 2016), 127-128.
} 
избора начина рада. Библиотекар информатор може развити личну технику претраживања електронске базе, лисног каталога, референсне литературе и осталих извора јер самосталност може да подстакне залагање и жељу за усавршавањем. Његова вештина, вођена унутрашњом мотивацијом, може бити подстицајна и за корисника. Аутономија која је дата библиотекару за осмишљавање сценарија радионице захтева, поред одговорности, мотивације и инспирације, знање о датој теми и креативност.

Аутономија може да се примени и у тимском раду. На пример, она може бити делотворна у великим пројектима као што су израда обимне библиографије или увођење иновација, ${ }^{13}$ када је потребно формирање привремених тимова одабраних људи из различитих одељења који добро функционишу зарад постизања дефинисаних циљева.

Пинк наводи и позитивне ефекте стратегије по којој запослени имају привилегију да 20\% радног времена самостално издвоје за рад према личним интересовањима. Током тих слободних сати настали су многи иновативни производи, нпр. Гугл транслејт (Google translate, програм за превођење) и Гугл ток (Google Talk, апликација за слање инстант порука). Дакле, насупрот контроле запослених, Пинк промовише развијање њихове самосталности у раду као кључ успеха.

Да ли је овакав став умесан и применљив у библиотекама у Србији и у којој мери је мото Вилијама Мекнајта ${ }^{14:}$ „Запосли добре људе и остави их на миру“ (не)примерен за овдашње прилике у којима не постоји служба за селекцију кандидата? Индивидуалан приступ руководилаца, праћење насупрот строге контроле квалитета рада библиотекара, њихових мотива и интересовања, подршка, отвореност за иновације, пружање шансе и стварање повољних околности за развијање потенцијала радника са једне стране и показивање иницијативе од самих библиотекара може водити ка додели и постизању аутономије за рад. Уз то, неопходна је жеља и увиђање потребе за сталним радом на личном и професионалном развоју и усавршавању.

\section{Библиотекар као узор у сталном усавршавању}

„Благо ономе ко зна да не зна, а хоће да зна.“ српска народна пословица ${ }^{15}$

Тежња ка усавршавању изискује труд, улагање напора (и новца), упорност, чак и одрицање у дужем периоду. Зато је важно питање начина на које се може пробудити тежња за самосталношћу и сталним усавршавањем у раду. Најважнији је проактиван став библиотекара кроз стално тражење узора и инспирације, примера добре праксе, нових знања и идеја за иновације у раду, у виду праћења домаће и стране литературе, похађања семинара и радионица, учешћа на конференцијама. Дакле, лично залагање у великој мери може довести до промена, боље понуде програма и већег броја корисника у библиотекама.

Овакав став је заступљен и на ширем међународном плану у библиотекарству. Међународна федерација библиотечких удружења и институција IFLA ${ }^{16}$ препознала је важност усавршавања у контексту континуираног учења на радном месту. ${ }^{17}$ Она се односи на подстицање

${ }^{13}$ Хилделис Балк, Елсбет Квант и Клеменс Недекер, „Шта чини иновације успешним? Искуство увођења иновација у Националној библиотеци Холандије“, Чишалишше год. 16, бр. 31 (новембар 2017): 44-55, преузето 30. 7. 2018, http://citaliste.rs/casopis/br31/ balk_hildelis.pdf.

${ }^{14}$ William L. McKnight (1887-1978), руководилац велике мултинационалне компаније 3M, залагао се за самосталност запослених, преузимање иницијативе и увођење иновација у рад.

${ }^{15}$ Edukacija, "Srpske narodne poslovice i izreke“, preuzeto 30. 7. 2018, http://edukacija.rs/izreke-i-citati/narodne-poslovice/srpske.

${ }^{16}$ Акроним од International Federation of Library Associations.

${ }^{17}$ IFLA, IFLA Guidelines for Continuing Professional Development: Principles and Best Practices, preuzeto 25. 7. 2018, https://www.ifla.org/ files/assets/cpdwl/guidelines/ifla-guidelines-for-continuing-professional-development.pdf. 
библиотекара да буду у току са технолошким и променама у друштву које се тичу библиотечко-информационе делатности, а библиотекари едукатори би требало да буду узори у доживотном учењу.

Стално стручно усавршавање библиотекара у Србији обавезно је и регулисано Законом о библиотечко-информационој делатности и Правилником о сталном стручном усавршавању у библиотечко-информационој делатности. Комисија за акредитацију сваке године одлучује о предложеним програмима. Питања квалитета и понуде програма превазилазе тему рада, али треба нагласити да увек постоји и могућност самоиницијативног усавршавања (стручна литература, едукација, онлајн курсеви ${ }^{18}$ и вебинари, нпр. IFLA Webinar: Library Map of the World ${ }^{19}$ ).

Пример како библиотекари могу оснаживати и подстицати младе на стицање знања је иновативни програм под називом Bridge up ${ }^{20}$ Јавне библиотеке у Њујорку. ${ }^{21}$ Младима се нуди стручна подршка у стицању различитих вештина: самосталности у раду, критичког мишљења, сарадње и креативности, неопходних за креирање личне визије и постизање успеха. Када говоримо о мотивисању младих корисника, треба споменути да се и у јавним библиотекама у Србији томе посвећује пажња у виду различитих конкурса и манифестација који имају за циљ подстицање читања и писања, или стицање различитих вештина. Навешћемо само неке примере добре праксе, за промовисање читања: Чишалачка значка (Народна библиотека Пирот, Народна библиотека Смедерево, Градска народна библиотека „Жарко Зрењанин“, Зрењанин, Библиотека града Београда), Јеgна књиїа - jegaн ірag (Градска библиотека Панчево); за промовисање писања: Књиїожgер (Библиотека шабачка), Голубић (Градска библиотека „Карло Бијелицки“, Сомбор), Драїи Деgа Мразе (Библиотека „Влада Аксентијевић“ Обреновац), Песничка

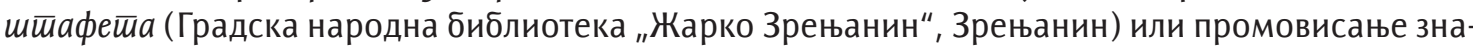
ња о свом завичају: едукативни програм Завичајни йојмовник (Народна библиотека „Његош“, Књажевац).

\section{Мисија библиотекара у друштву}

„Самостални људи који теже савршенству постижу сјајне резултате, али они који то раде зарад неког вишег циља постижу још више."

Данијел Пинк 22

За илустрацију важности сврсисходности личног рада и природе мотива за рад послужиће три различита става библиотекара који раде на дечјем одељењу једне јавне библиотеке. Став првог библиотекара може се описати речима: „Радим овај досадан посао, седим и чекам мале давеже да узму или врате књиге, а тек што волим да их нагрдим кад окасне." Став другог гласи: „Издајем књиге, плата је мала, али редовна, пријављен сам и имам релативно сигуран посао. Желим да својој породици обезбедим нормалан живот." Трећи библиотекар мисли на следећи начин: „Радим у кући која деци нуди непроцењиво знање. Ко зна, можда се међу овом децом налази будући нобеловац, научник, или политичар који ће побољшати живот у Србији!"

Какве последице могу изазвати наведени ставови библиотекара код корисника? Деца ће библиотекара са првим ставом вероватно избегавати, називати га погрдним именима или

\footnotetext{
${ }^{18}$ Coursera, preuzeto 30. 7. 2018, https://www.coursera.org.

${ }^{19}$ IFLA, IFLA Webinar: Library Map of the World, preuzeto 30. 7. 2018, https://www.ifla.org/node/61889.

${ }^{20}$ New York Public Library, BridgeUp, preuzeto 30. 7. 2018, https://www.nypl.org/ost/bridgeup.

${ }^{21}$ The New York Public Library.

${ }^{22}$ Daniel Pink, Nav. delo, 151
} 
каснити са враћањем књига јер није довољно мотивисан, код другог ће свраћати само кад им је потребна домаћа лектира јер га покреће превасходно новац (спољашња мотивација), а код трећег ће радо свраћати јер увек има да понуди неку занимљиву радионицу или књигу, зато што га покрећу унутрашњи мотиви (и инспирација), свестан је сврхе и ширег значаја који књиге и библиотека могу имати у друштву. Дакле, ефекат мотивације и сврсисхоgносиии рада на продуктивност и квалитет пружања услуге може бити евидентан у ширем смислу и градити реноме библиотекара у друштву.

\section{Уметност постављања циљева}

„Ко не зна у коју луку плови, њему ниједан ветар није повољан.“ Еврипид 23

Циљеви воде и усмеравају активност, генеришу нове (креативне) стратегије, планирање, ефикасну поделу рада и доношење одлука у свакој фази процеса реализације. У том процесу може бити много фаза и међуфаза, успеха и неуспеха, а мотивација је фактор упорности и истрајности на путу ка циљу.

У чему је тајна добро постављеног циља ${ }^{24}$ Да би био остварен, потребно је да буде јасно дефинисан, мерљив, достижан, реалан и са прецизно одређеним роком реализације. Узбуђење и награђујући ефекат су оно што додатно доприноси његовом достизању. Лични циљеви библиотекара требало би да су сврсисходни и у складу са циљевима библиотеке, а они усклађени са још ширим, дефинисаним на националном нивоу. ${ }^{25}$ Неки од релевантних циљева из актуелног Предлога Стратегије за развој културе Републике Србије 2017-2027. су: развој читалачке културе, развој нормативног оквира, ширење библиотечке мреже, развој људских ресурса, просторних услова и опреме у библиотекама, унапређење набавне политике књига и остале библиотечке грађе.

На међународном плану, за илустрацију навешћемо актуелне циљеве одрживог развоја у оквиру глобалне развојне агенде Уједињених нација за период до 2030. године (Агенда УН 2030). ${ }^{26}$ Циљ (16.10) који се односи на библиотеке гласи: „Осигурати јавни приступ информацијама и заштити основне слободе у складу са националним законима и међународним договорима". Поред приступа информацијама, међу релевантним циљевима за библиотеке су: очување културног наслеђа (11.4), универзална писменост (део визије УН) и приступ информационо-комуникационим технологијама (17.8).

У раду који описује стратегију увођења иновација у Националној библиотеци Холандије, међу факторима који одређују капацитет институције за увођење иновација, аутори наводе и важност да се циљеви иновација подударају са стратешким циљевима организације. ${ }^{27}$ Циљеви играју кључну улогу у постигнућу и ефикасности. То потврђује податак да је у великом броју студија (90\%), постављање специфичних и изазовних циљева доводило до већег учинка у односу на постављање лаких, „уради најбоље што можеш“, или када их није ни било. ${ }^{28}$

\footnotetext{
${ }^{23}$ Business Academy, Poslovne misli za sva vremena: poslovice, misli, izreke, preuzeto 1. 8. 2018, http://www.razvoj-karijere.com/media/ files/misliWEB.pdf.

${ }^{24}$ СМАРТ циљ, настао у оквиру Теорије постављања циљева, аутора Питера Дракера (Peter F. Drucker, 1909-2005).

25 Поглавље 3.2.1. Књижевност, издаваштво и библиотечко-информациона делатност у „Предлог Стратегије развоја културе Републике Србије од 2017. до 2027.“, преузето 26. 8. 2018, http://www.kultura.gov.rs/docs/dokumenti/predlog-strategije-razvoja-kulture-republike-srbije-od-2017--do-2027-/-predlog-strategije-razvoja-kulture-republike-srbije-od-2017--do-2027-.pdf.

${ }^{26}$ Biblioteke 2030, Ciljevi održivog razvoja, preuzeto 26. 7. 2018, https://biblioteke2030.wordpress.com/ciljevi-odrzivog-razvoja/.

27 Балк, Квант и Недекер, Нав. дело.

${ }^{28}$ Edwin A. Locke et al., “Goal setting and task performance: 1969-1980“, Psychological Bulletin 90, 1 (1981), preuzeto 25. 7. 2018, http:// psycnet.apa.org/doiLanding?doi=10.1037\%2F0033-2909.90.1.125
} 
У процесу постављања циљева (личних или организационих) може бити корисна SWOT29 анализа, метода за стратешко планирање која служи за евалуацију унутрашњих фактора снага и слабости на личном плану, као и спољашњих фактора - шанси и претњи у организацији. Такође, потребно је истаћи и утицај надређених (ментора). Да би библиотекар прихватио циљеве који су му постављени, потребно је омогућити његово активно учешће у њиховом доношењу. Да се не би изгубио смер кретања ка циљу, потребно је редовно тражење и пружање

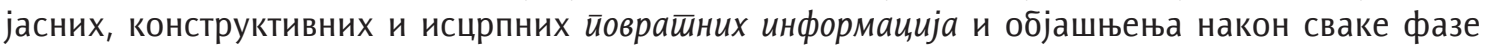
рада, којима се прилагођавају, подешавају поступци и активности.

\section{Потребе као покретачи}

„...када говоримо о потребама људских бића, говоримо о сушешини њихових бића.“ Абрахам Маслов ${ }^{30}$

Абрахам Маслов, клинички психолог и зачетник хуманисиичике йсихолоїије, правца који је истицао раст и развој здраве личности, развио је теорију мотивације у којој као круцијални узрок било које активности поставља тежњу за задовољавањем различитих потреба по природном редоследу: од физиолошких, које обезбеђују опстанак (храна, вода, сан), за сигурношћу (заштићеност од хладноће и опасности), преко друштвених потреба (међуљудски односи, припадност групи, за љубављу), потребе за признањем, поштовањем и самопоштовањем (углед, статус), до потребе за самоостварењем, самоактуелизацијом (тежња да се напредује, развија, сазнаје, да се остваре сви лични потенцијали). Теорија је оспоравана у експерименталним истраживањима која нису потврдила основне постулате: да основних пет категорија не може у потпуности описати феномен мотивације, да интензитет мотивације опада са степеном задовољености мотива, као ни да је редослед задовољења потреба доследан. ${ }^{31}$ Ипак, она може пружити општу информацију о изражености потреба.

Које су се то потребе, према Масловљевој теорији, издвојиле код библиотекара у Србији? У досадашњим групама библиотекара током радионице на тему мотивације ${ }^{32}$ на тесту конструисаном према наведеној теорији, од укупно пет категорија, две су се показале најизраже-

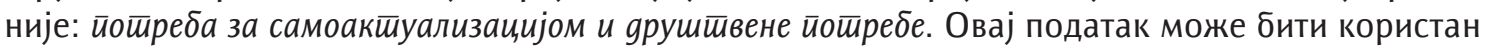
за руководиоце библиотека, библиотекарска друштва и комисије, да размотре да ли издвојене потребе могу бити задовољене у оквиру библиотечко-информационог система, како би се обезбедили лични раст и развој, као и напредак функционисања целог система. Конкретно, да ли постоје одговарајући и довољно разнолики едукативни програми за стручно усавршавање из различитих области (поред библиотекарства, информатика, психологија, вештине подучавања, вођење радионица, учење страних језика и др.), могућност одласка на међународне конференције; разрађен, праведан бодовни систем за доделу стручних звања; програми који поспешују тимски рад, екскурзије.

Важно је напоменути да би праћење потреба, као и интереса, предлога и свакодневних проблема библиотекара било пожељно на недељном или месечном нивоу. Тиме би се побољшала интерна комуникација на нивоу руководилац-подређени и кроз редовне разговоре, а показивањем искреног интереса за појединца могли би се брже открити и решити текући проблеми. Овакав индивидуалан приступ може боље повезати личне циљеве са визијом и мисијом

\footnotetext{
${ }^{29}$ Акроним од strengths, weaknesses, opportunities, threats. Њен творац је амерички менаџмент консултант Алберт С. Хамфри (Albert S. Humphrey, 1927-).

${ }^{30}$ Abraham Maslov, Motivacija i ličnost (Beograd: Nolit, 1982), 47.

31 Milivojević, Motivacija za rad: teorije i strategije, 78.

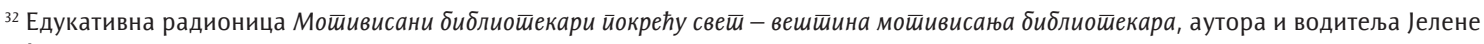
Јовин.
} 
библиотеке и тиме допринети њиховом међусобном усклађивању. За успех библиотеке потребно је усклађивање рада и понуде програма са потребама корисника, и њихово праћење путем књиге утисака или у виду годишњих анкета.

Дакле, праћење потреба и мотивисање запослених, рад са тимовима, умеће комуникације само су неке од вештина неопходних за ефикасно управљање и стварање продуктивног радног окружења. Зато је захтев за сталним усавршавањем библиотекара из области психологије рада и менаџмента, нарочито руководилаца, врло индикативан за постизање бољег квалитета рада библиотека.

\section{Трансакционо-аналитички концепт унутрашње мотивације}

„Свако носи Сенку, и што је она мање укључена у свесни живот појединца, тамнија је и гушћа." Карл Густав Јунг ${ }^{33}$

Према Трансакционој анализи ${ }^{34}$ разликује се пет типичних стилова рада ${ }^{35}$ названих: Пожури, Буgи савршен, Уgовољи gруїима, Труgи се и Буgи јак. ${ }^{36}$ Они одређују начин на који организујемо рад и време, како функционишемо са другима и у тимском раду, како комуницирамо. Важно је истаћи да сваки од ових стилова понашања има како позитиван аспект (свесно понашање у оптималним условима рада), тако и негативан, изражен у стресним ситуацијама, препознатљив у трансакционо-аналитичкој термиологији као gрајвер. ${ }^{37}$ Према Џули Хеј „то су несвесни покушаји да се понашамо на начин којим бисмо стекли потребно препознавање од других"38 и формирају се током детињства у односима детета са одраслим особама (деца одговарају на поруке важних одраслих особа покушавајући да им удовоље). Већина људи у понашању доминантно испољава карактеристике два различита стила, а повећана свесност о њима може помоћи да учврстимо своје предности и смањимо стварање грешака и проблема. ${ }^{39}$

За илустрацију пет основних радних стилова послужиће опис понашања виртуелних библиотекара који имају исти задатак, да за месец дана напишу предлог пројекта за радионицу са циљем подстицања читања код деце.

Библиотекар који је брз у свему, уме истовремено да прекуцава текст и одговара на позиве корисника, а писање пројекта пролонгира док не дође у коштац с временом, јер „воли“ да ради под притиском. Међутим, у журби прави грешке које нема времена да исправи, па касни или предаје пројекат лошијег квалитета. Често делује нестрпљиво и зато другима завршава реченице, на нетачан начин. Покреће га брзина (драјвер Пожури), која му може помоћи, али и одмоћи у раду. Његова ефикасност у раду била би повећана поделом задатка на делове и одређењем временског рока за сваки, више пажње усмерено на саговорника унапредило би комуникацију.

\footnotetext{
${ }^{33}$ Karl Gustav Jung, Psihologija i religija: Zapad i Istok (Beograd: Atos-DK, 2017), 91

${ }^{34}$ Теорија личности и комуникације чији је идејни творац психијатар Ерик Берн (Eric Berne, 1910-1970), настала крајем педесетих година 20. века у Сан Франциску под утицајем психоанализе. Данас се примењује у психотерапији, саветовању, педагогији и менаџменту.

${ }^{35}$ Термин је увела Џули Хеј (Julie Нау 1942-).

36 У Трансакционој анализи сви називи концепата пишу се великим почетним словом.

${ }^{37}$ Термин је увео Таиби Кахлер (Taibi Kahler 1943-). Кованица потиче од eng. driver у значењу покретач.

${ }^{38}$ Julie Hay, Drivers and Working Styles an Essay, 2013, preuzeto 30. 7. 2018, https://www.juliehay.org/uploads/1/2/2/9/12294841/drivers_working_stlyes_an_essay.pdf.

${ }^{39}$ Julie Hay, "Working Styles", in Working It Out at Work: Understanding Attitudes and Building Relationships (London: Sherwood Publishing, 2009), 76, preuzeto 30. 7. 2018, https://www.juliehay.org/uploads/1/2/2/9/12294841/wow_chapter_6_web.pdf.
} 
Други стил би представљало понашање библиотекара који све што ради, ради без грешке, тачно на време и има репутацију особе од поверења, јер се темељно припрема и пажљиво проверава све детаље садржаја и форме. Он почиње са израдом предлога задатог пројекта на време, придржава се плана, пажљиво саставља реченице, користећи стручне термине, другима тешко разумљиве и уноси честе измене да би постигао савршенство. Ако примети грешку, осећа се незадовољно и мање вредно. Нема поверења у квалитет рада других колега и зато не делегира посао, а важи и за оштрог критичара. Овакво понашање у основи има иеерфекиионизам (драјвер Буgи савршен) са својим добрим и лошим аспектима. Постављање мало реалнијих стандарда за тачност и време израде и конструктивније критиковање других могло би смањити тензију и повећати ефикасност.

Трећи стил рада може бити описан терминима: воли да се дружи и посвећује пажњу другима, одличан је тимски играч, хармонични односи су му важни, никада не вређа, нити критикује (чак и када је потребно), да не би повредио осећања других. Преферира да се смешка, одобрава и прихвата послове остављајући личне приоритете по страни и зато касни са пројектом. Пошто се устеже да пита и тражи додатне информације, задатак може да уради на погрешан начин. Радне перформансе оваквог стила могу бити побољшане израдом плана завршавања задатка и његовим истрајним придржавањем до окончања, као и усмеравањем пажње само на важне аспекте пројекта. Наведени стил понашања у великој мери покреће мотив удовољавања gруїима (драјвер Уі̄ogu gруїима), а постизање бољих резултата може бити побољшано учењем вештине постављања граница према другима (асертивно понашање).

Следећи библиотекар је вечити ентузијаста и радо прихвата нове задатке, често и волонтерски, што га чини омиљеним међу колегама. Он ће темељно простудирати све аспекте пројекта и размишљати о онима које други превиђају. Међутим, он се више йрygu (драјвер Tpygu ce) него што успева, расплињује се и губи у измени садржаја пројекта, што доводи до кашњења или до пројекта са превише ирелевантних информација. Побољшање радних перформанси може донети престанак волонтирања и израда озбиљног плана спровођења пројекта који укључује и сам крај, толико недостижан за њега и усмеравање пажње само на аспекте који се директно односе на њега и чије резултате други очекују.

Библиотекар који остаје смирен и трезвен, без изражавања емоција чак и у стресним ситуацијама (драјвер Буgи јак), одговорно и савесно прихвата непријатне задатке, врло је љубазан, а његова критика је искрена и конструктивна. Врло је самокритичан и тражење помоћи сматра изразом неспособности и слабости и зато не делегира посао, преузимајући све задатке. Колеге га доживљавају као безосећајног и недодирљивог. Пројекат ће урадити сам, јер он то најбоље зна и зато не тражи помоћ. Више ефикасности и побољшање односа са колегама донело би тражење помоћи од других, а праћење тока рада пружило би преглед оптерећености послом и могућност конструктивне прерасподеле задатака.

Препознавање личних, као и стилова рада колега са предностима и манама, може бити корисно у првом реду за лични раст, развој и тежњу ка промени у циљу постизања максималних радних перформанси. Затим је корисно руководиоцима за ефикаснију поделу радних задатака, а библиотекарима за међусобно прилагођавање и бољу организацију радних задатака у тимском раду. И треће, уместо да захтевају мењање навика библиотекара, руководиоци могу, познавањем индивидуалног радног стила, поставити праву особу на право место, тј. дати одговарајуће задатке како би предности његовог радног стила дошле до изражаја. На пример, особине којег драјверског понашања су повољне за брзо и тачно извршавање задатака, који профил би одговарао за рад са особама са „тешким“ понашањем, ко би добро водио пројекат и тим, а ко је добар за вођење радионица. 


\section{Уместо закључка: лична стратегија и акциони план}

„Уколико нису спречени, људи расту како би се суочили са изазовима. Окружење у којем функционишемо или допушта нашим скривеним могућностима да се развијају или чини да оне замру. “

Исак Адижес ${ }^{40}$

Претходне теоријске белешке могу бити смернице библиотекарима у планирању каријере. Оне су нека врста подсетника о природи личне мотивације: врстама потреба које имамо, предностима и манама стила којим радимо, карактеристикама циљева које смо поставили, тежњи ка аутономији, сталном усавршавању и општој, а не само личној, сврси због које радимо.

Иако не мање важна питања мотивационог утицаја радне атмосфере, постојања подршке ментора или статуса библиотечке струке у друштву, она су остала по страни као мање вероватне променљиве, зарад промовисања личног става и залагања у раду. Не умањујући ни значај новчане награде и под претпоставком да код читаоца не постоји горчина због неправде у подели зарада, рад је имао за циљ да промовише мотиве који превазилазе задовољавање основних личних, егзистенцијалних и потреба сигурности. Да ли умемо да уживамо у раду, да ли смо спремни да уложимо труд, да се одрекнемо нечег у корист усавршавања? Да ли је могуће радити зарад осећаја самоиспуњења, са оптимизмом, стварати занимљиве, изазовне циљеве, бити креативан, помагати другима у њиховом расту и развоју, јер библиотеке јесу куће знања, доступне свима који желе да га стичу, расту и напредују. Запитајмо се да ли имамо професионалне циљеве и како се они уклапају у организациону политику и доприносе библиотеци. Уосталом, време пролази, а каријера је једна и великим делом је у нашим одлукама. Поред личне спремности, да ли имамо ментора који ће нам дати подршку и смернице када се створе повољне околности за промену радне позиције?

И за крај, даћемо предлог израде личне стратегије и акционог плана за период од годину дана, са конкретним пословним циљевима који су у складу са личним жељама као и мисијом библиотеке и који је употпуњен јасним корацима и конкретним активностима за реализацију. План би требало да укључи начине за јачање личних недостатака путем стицања нових или усавршавања постојећих знања и способности. На тај начин библиотекар може, пратећи своје резултате и напредак у остваривању циљева, стећи увид у тренутну позицију на путањи личног и професионалног развоја и одредити правац којим жели кретати ка успеху.

\section{Литература и извори:}

1. Adižes, Isak. Misli: povodom 75 godina života i 50 godina rada. Novi Sad: Asee, 2012.

2. Balk, Hildelis, Elsbet Kvant i Klemens Nedeker. „Šta čini inovacije uspešnim? Iskustvo uvođenja inovacija u Nacionalnoj biblioteci Holandije". Čitalište god. 16, br. 31, (novembar 2017): 44-55. Preuzeto 30. 7. 2018. http://citaliste.rs/casopis/br31/balk_hildelis.pdf.

3. Biblioteke 2030. Ciljevi održivog razvoja. Preuzeto 26. 7. 2018. https://biblioteke2030.wordpress.com/ ciljevi-odrzivog-razvoja/.

4. Business Academy. Poslovne misli za sva vremena: poslovice, misli, izreke. Preuzeto 1. 8. 2018. http://www. razvoj-karijere.com/media/files/misliWEB.pdf.

5. Coursera. Preuzeto 30. 7. 2018. https://www.coursera.org.

6. Edukacija. „Srpske narodne poslovice i izreke“. Preuzeto 30. 7. 2018. http://edukacija.rs/ izreke-i-citati/narodne-poslovice/srpske.

7. Hay, Julie. Drivers and Working Styles an Essay. 2013. Preuzeto 30. 7. 2018. https://www.juliehay.org/ uploads/1/2/2/9/12294841/drivers_working_stlyes_an_essay.pdf.

\footnotetext{
${ }^{40}$ Adižes, Misli: povodom 75 godina života i 50 godina rada, 148.
} 
8. Hay, Julie. "Working Styles". In Working It Out at Work: Understanding Attitudes and Building Relationships, 73-87. London: Sherwood Publishing, 2009. Preuzeto 30. 7. 2018. https://www.juliehay.org/ uploads/1/2/2/9/12294841/wow_chapter_6_web.pdf.

9. IFLA. IFLA Guidelines for Continuing Professional Development: Principles and Best Practices. Preuzeto 25. 7. 2018. https://www.ifla.org/files/assets/cpdwl/guidelines/ifla-guidelines-for-continuing-professionaldevelopment.pdf.

10. IFLA. IFLA Webinar: Library Map of the World. Preuzeto 30. 7. 2018. https://www.ifla.org/node/61889.

11. Jung, Karl Gustav. Psihologija i religija: Zapad i Istok. Beograd: Atos-DK, 2017.

12. Locke, Edwin A., Karyll N. Shaw, Lise M. Saari, and Gary P. Latham. "Goal setting and task performance: 1969-1980." Psychological Bulletin 90, 1 (1981). Preuzeto 25. 7. 2018. http://psycnet.apa. org/doiLanding?doi=10.1037\%2F0033-2909.90.1.125.

13. Maslov, Abraham. Motivacija i ličnost. Beograd: Nolit, 1982.

14. Montesori, Marija. Upijajući um. Beograd: Miba Books, 2016.

15. Milivojević, Tatjana. Motivacija za rad: teorije i strategije. Beograd: „Filip Višnjić", 2009.

16. Ministarstvo kulture i informisanja Republike Srbije. „Predlog Strategije razvoja kulture Republike Srbije od 2017. do 2027“. Preuzeto 26. 8. 2018. http://www.kultura.gov.rs/docs/dokumenti/predlogstrategije-razvoja-kulture-republike-srbije-od-2017--do-2027-/-predlog-strategije-razvoja-kulturerepublike-srbije-od-2017--do-2027-.pdf.

17. New York Public Library. BridgeUp. Preuzeto 30. 7. 2018. https://www.nypl.org/ost/bridgeup.

18. Pink, Daniel. Šta nas pokreće: neočekivana istina o ljudskoj motivaciji. Beograd: Laguna, 2011.

19. Priceless Professional Development. "How to Define Motivation and Inspiration: the Power of the Difference". Preuzeto 25. 7. 2018. https://www.pricelessprofessional.com/define-motivation-andinspiration.html.

20. Trebješanin, Žarko. Rečnik psihologije. Beograd: Stubovi kulture, 2004.

21. Vujanić, Milica, Darinka Gortan-Premk, Milorad Dešić, Rajna Dragićević, Miroslav Nikolić, Ljiljana Nogo, Vasa Pavković, Nikola Ramić, Rada Stijović, Milica Tešić i Egon Fekete. Rečnik srpskoga jezika. Novi Sad: Matica srpska, 2007.

22. "Zakon o bibliotečko-informacionoj delatnosti“. Sužbeni glasnik RS br. 52 (2011). Preuzeto 30. 7. 2018 https://www.nb.rs/view_file.php?file_id=3047.

\section{Intrinsic Work Motivation of Librarians}

\section{Summary}

There are obvious differences in working styles and levels of productivity among librarians. Some of the catalogists are faster in reaching the monthly norm, some of the reference librarians are more popular among users, some librarians are faster in gaining the higher titles, some are better in making professional contacts on conferences or within social networks, and some willingly work overtime. What makes the difference, drives them, gives strength, desire and will for work? Besides the unique personality traits, temperament, inteligence, this article reveals the phenomenon of motivation as the key determinant, which has been investigated by authors within different theoretical frameworks in management and organizational psychology. The topic includes several aspects, beginning with the personal, through the aspect of others (colleagues, mentors, working environment) to the wider social, cultural and economic environment in which a library operates. The main intention is to highlight the complexity and the value of the intrinsic work motivation by indicating different theoretical approaches of Daniel Pink, Ichak Adizes, Abraham Maslow and transactional-analysists, which could be guidance in personal practice. The theoretical background is followed by some examples from library practice and the author's personal experience in conducting a workshop on motivation.

Keywords: librarians, mission, work styles, motivation, goals, professional development 


\section{(ब)}

Унутрашња мотивација за рад библиотекара bу Јелена Јовин is licensed under a Creative Commons Attribution-NonCommercial-NoDerivatives 4.0 International License. 